\title{
Pembelajaran Afeksi
}

\section{Misbahul Munir*}

\begin{abstract}
ABSTRAK
In school learning; In addition aspects of intellectual formation to shape the intelligence of learners and the formation of skills to develop competence, so the learners must have motoric skills, then the attitudes of learners is an aspect that is not less important.

The process of education is not only forming intelligence or providing certain skills, but also establish and develop attitudes so that children have an accordance with the norms prevailing in society.

Affective learning is related to value, which is difficult to measure because it involves awareness of someone who grows from within. This is not easy in the planting so it takes a serious and continuous effort both in school and when under the supervision of parents at home.

Because of the importance of affective learning it is a necessity for educators to be more intensive in its implementation and do not consider if the affective learning does not include interests in making students as a superior generation who will live in the future and ready in all of challenges
\end{abstract}

Keywords: Process of education, Affective learning, Norms of prevailing in society 


\section{PEMBELAJARAN AFEKSI}

Dalam undang-undang No. 20 Tahun 2003 Pasal 3 dijelaskan bahwa Pendidikan Nasional berfungsi mengembangkan kemampuan dan membentuk watak serta peradaban bangsa yang bermartabat dalam rangka mencerdaskan kehidupan bangsa, bertujuan untuk berkembangnya potensi peserta didik, agar menjadi manusia yang beriman dan bertakwa kepada Tuhan Yang Maha Esa, berakhlak mulia, sehat, berilmu, cakap, kreatif, mandiri, dan menjadi warga Negara yang demokratis serta bertanggung jawab.

Rumusan tujuan pendidikan di atas, sarat dengan pembentukan sikap. Dengan demikian, tidaklah lengkap manakala dalam strategi pembelajaran tidak membahas strategi pembelajaran yang berhubungan dengan pembentukan sikap dan nilai.

Ada orang yang beranggapan bahwa sikap bukan untuk dijarkan, seperti halnya matematika,fisika dan lain sebagainya, akan tetapi untuk dibentuk. Oleh karena itu, yang lebih tepat untuk bidang afektif bukanlah istilah pengajaran, namun pendidikan. Namun, oleh karena strategi pembelajaran yang dibicarakan dalam makalah ini diarahkan untuk mencapai tujuan pendidikan yang bukan hanya dimensi kognitif tetapi juga demensi yang lainnya, yaitu sikap dan keterampilan, melalui proses pembelajaran yang menekankan kepada aktifitas siswa sebagai subyek belajar, maka selanjutnya kita menggunakan istilah pembelajaran afektif, walaupun dalam bahasan selanjutnya kedua istilah itu akan digunakan secara bergantian.

Strategi pembelajaran afektif memang berbeda dengan strategi pembelajaran kognitif dan keterampilan. Afektif berhubungan dengan nilai (value), yang sulit di ukur, oleh karena menyangkut kesadaran seseorang yang tumbuh dari dalam. Dalam batas tertentu memang afeksi dapat muncul dalam kejadian behavioral, akan tetapi penilaiannya untuk sampai pada kesimpulan yang bisa di pertanggung jawabkan membutuhkan ketelitian dan observasi yang terus menerus, dan hal ini tidaklah mudah unt uk dilakukan, apalagi menilai perubahan sikap sebagai akibat dari proses pembelajaran yang dilakukan guru disekolah. Kita 
tak bisa menyimpulkan bahwa sikap anak itu baik, misalnya dilihat dari kebiasaan berbahasa atau sopan santun yang bersangkutan,sebagai akibat dari proses pembelajaran yang dilakukan guru. Mungkin sikap itu terbentuk oleh kebiasaan dalam keluarga dan lingkungan sekitar.

Hakikat Pendidikan Nilai dan Sikap

Dimuka telah dijelaskan bahwa sikap (afektif) erat kaitannya dengan nilai yang dimiliki seseoarang. Sikap merupakan refleksi dari nilai yang dimiliki.Oleh karenanya pendidikan sikap pada dasarnya adalah pendidikan nilai.

Nilai adalah suatu konsep yang berada dalam pikiran manusia yang sifatnya tersembunyi, tidak berada dalam dunia yang empiris. Nilai berhubungan dengan pandangan seseorang tentang baik dan buruk, indah atau tidak indah, layak dan tidak layak, adil dan tidak adil dan lain sebagainya. Pandangan seseorang tentang hal itu tidak bisa diraba, kita hanya mungkin dapat mengetahuinya dari perilaku yang bersangkutan. Oleh karena itulah nilai pada dasarnya standar perilaku, ukuran yang menentukan atau ceriteri seseorang tentang baik atau tidak baik, indah atau tidak indah, layak atau tidak layak dan lain sebagainya, sehingga standar itu yang akan mewarnai perilaku seseorang. Dengan demikian, pendidikan nilai pada dasarnya proses penanaman nilai kepada peserta didik yang di harapkan. Oleh karena itu siswa dapat berperilaku sesuai dengan pandangan yang dianggapnya baik atau tidak bertentangan dengan normanorma yang berlaku.

Ada empat faktor yang merupakan dasar kepatuhan seseorang terhadap nilai tertentu, yaitu; ${ }^{1}$

a. Normativist. Biasanya kepatuhan pada norma- norma hukum.kepatuhan ini terdapat dalam tiga bentuk, yaitu;(1) kepatuhan terhadap norma itu sendiri. (2) kepatuhan terhadap proses tanpa memedulikan normanya sendiri, (3) kepatuhan terhadap hasilnya.

b. Integralist, yakni kepatuhan yang didasarkan pada kesadaran dengan pertimbangan-pertimbangan yang rasionalis.

c. Fenomenalist, yaitu kepatuhan berdasarkan suara hati atau sekadar basa-basi. 
d. Hedonist, yaitu kepatuhan berdasarkan kepentingan diri sendiri.

Dari keempat factor yang menjadi dasar kepatuhan setiap indifidual tentu saja yang kita harapkan adalah kepatuhan yang bersifat normativist, sebab kepatuhan semacam itui adalah kepatuhan yang didasari kesadaran akan nilai, tanpa memedulikan apakah perilaku itu menguntunkan untuk dirinya atau tidak.

Selanjutnya dalam sumber yang sama dijelaskan, dari empat factor ini terdapat lima tipe kepatuhan, yaitu;

a. Otoritarian. Suatu kepatuhan tanpa reserve atau kepatuhan yang ikut-ikutan.

b. Conformist. Kepatuhan tipe ini mempunyai tiga bentuk yaitu; (1) conformist directed, yaitu penyesuaian diri terhadap masyarakat atau orang lain. (2) conformist hedonist, yakni kepatuhan yang berorientasi pada "untung-rugi", dan (3) conformist integral, adalah kepatuhan yang menyesuaikan kepentingan diri sendiri dengan kepentingan masyarakat.

c. Compulsive deviant, yaitu kepatuhan yang tidak konsisten.

d. Hedonic psikopatik, yaitu kepatuhan pada kekayaan tanpa memperhitungkan kepentingan orang lain.

e. Supra moralist. Kepatuhan karena keyakinan yang tinggi terhadap nilai-nilai moral.

Dalam masyarakat yang cepat berubah seperti dewasa ini,pendidikan anak merupakan hal yang sangat penting. Hal ini disebabkan pada era global dewasa ini, anak akan dihadapkan pada banyak pilihan tentang nilai yang dianggapnya baik. Pertukaran dan pengkikisan nilai-nilai suatu masyarakat dewasa ini akan mungkin terjadi secara terbuka. Nilai-nilai yang dianggap baik oleh suatu kelompok masyarakat bukan tak mungkin menjadi luntur digantikan oleh nilainilai baru yang belum tentu cocok dengan budaya masyarakat.

Nilai bagi seseorang bukanlah statis, akan tetapi selalu berubah. Setiap seseorang akan mengaggap sesuatu itu baik sesuai dengan pandangannya saat itu. Oleh sebab itu, maka system nilai yang dimiliki seseorang itu bisa dibina dan diarahkan. Apabila seseorang mengaggap nilai agama adalah di atas segalanya, maka nilai-nilai yang lain akan bergantung pada nilai agama itu. Dengan demikian 
sikap seseorang sangat tergantung pada system nilai yang dianggapnya paling benar, dan kemudian sikap itu yang akan mengendalikan perilaku orang tersebut. ${ }^{2}$

Pernyataan kesenangan dan ketidaksenangan seseorang terhadap obyek yang dihadapinya, akan sangat dipengaruhi oleh tingkat pemahamannya (aspek kognitif) terhadap obyek tersebut. Oleh karena itu tingkat penalaran (kognitif) terhadap suatu obyek dan kemampuan untuk bertindak terhadapnya (psikomotorik) turut menentukan sikap seseorang terhadap obyek yang bersangkutan. Misalnya, seseorang dapat memberikan penjelasan dari berbagai sudut bahwa mencuri itu tidak baik dan dilarang oleh norma apapun (aspek kognitif). Berdasarkan pengetahuannya itu ia tidak suka melakukannya(aspek efektif), akan tetapi sikap negative terhadap perbuatan mencuri baru bisa kita lihat dari tindakan nyata bahwa walaupun ada kesempatan untuk mencuri ia tidak melakukannya. Dan, penilaian terhadap sikap negative terhadap mencuri itu lebih meyakinkan bahwa perbuatan mencuri itu memang tidak pernah ia lakukan, walaupun banyak kesempatan untuk itu.

Model Strategi Pembelajaran Sikap

Setiap strategi pembelajaran sikap pada umumnya menghadapkan siswa pada situasi yang mengandung konflik atau situasi yang problematik. Melalui situasi ini siswa diharapkan dapat mengambil keputusan berdasarkan nilai yang dianggapnya baik. Di bawah ini disajikan beberapa model strategi pembelajaran pembentukan sikap.

\section{Model Konsiderasi}

Model konsederasi (the consideration model) dikembangkan oleh Mc. Paul, seorang humanis. Paul mengaggap bahwa pembentukan moral tidak sama dengan pengembangan kognitif yang rasional. Pembelajaran moral siswa menurutnya adalah pembentukan kepribadian bukan pengembangan intelektual. Oleh sebab itu, model ini menekankan pada strategi pembelajaran yang dapat membentuk kepribadian. Tujuannya adalah agar siswa menjadi manusia yang memiliki kepedulian terhadap orang lain. Kebutuhan yang fundamental pada manusia adalah bergaul secara harmonis dengan orang lain, saling memberi dan menerima dengan penuh cinta dan kasih saying.dengan 
demikian, pembelajaran sikap pada dasarnya adalah meambantu anak agar dapat mengembangkan kemampuan untuk bisa hidup bersama secara harmonis, peduli dan merasakan apa yang dirasakan orang lain.

Atas dasar asumsi diatas guru harus menjadi model didalam kelas dalam memperlakukan siswa dengan rasa hormat, menjauhi sikap otoriter

Implementasi model konsideransi guru dapat mengikuti tahapan pembelajaran seperti berikut: ${ }^{3}$

a. Menghadapkan siswa pada suatu masalah yang mengandung konflik, yang sering terjadi dalam kehidupan sehari-hari.Ciptakan situasi” seandainya siswa ada dalam masalah tersebut.

b. Menyuruh siswa untuk menganalisis situasi masalah dengan melihat bukan hanya yang tampak, tapi juga yang tersirat dalam permasalahan tersebut, misalnya perasaan, kebutuhan dan kepentingan orang lain.

c. Menyuruh siswa untuk menuliskan tanggapannya terhadap permasalahan yang dihadapi. Hal ini dimaksudkan agar siswa dapat menelaah perasaannya sendiri sebelum ia mendengar respon orang lain untuk dibandingkan.

d. Mengajak siswa untuk menganalisis respon orang lain serta membuat kategori dari setiap respon yang diberikan siswa.

e. Mendorong siswa untuk merumuskan akibat atau konsekuensi dari setiap tindakan yang diusulkan siswa. Dalam tahapan ini siswa diajak berfikir tentang segala kemungkinan yang akan timbul sehubungan dengan tindakannya.

f. Mengajak siswa untuk memandang permasalahan dari berbagai sudut pandang(interdisipliner) untuk nmenambah wawasan agar meraka dapat menimbang sikap tertentu sesuai dengan nilai yang dimilikinya.

g. Mendorong siswa agar merumuskan sendiri tindakan yang harus dilakukan sesuai dengan pilihannya berdasarkan pertimbangannya sendiri. Guru hendaknya tidak menilai benar atau salah atas pilihan siswa. Yang diperlukan adalah guru dapat membimbing mereka menentukan pilihan yang lebih matang sesuai dengan pertimbangannya sendiri. 


\section{Model Pembelajaran Afeksi menurut Syekh al-Zarnuji (Ta'limul Muta'allim)}

Dalam konteks agama Islam maka mencari ilmu adalah suatu kewajiban yang harus di lakukan dengan tidak boleh meninggalkan tatanan syariat untuk mendapatkannya. Maka secara Islami menuntut ilmu harus juga di barengi dengan sikap pembentukan moral yang baik karena sebuah proses pembelajaran akan berhasil dengan baik apabila moralitas peserta didik juga baik.

Menurut Zarnuji maka yang pertama kita harus berniat yang sungguh-sungguh dalam mencari ilmu dibarengi dengan keikhlasan. Begitu juga pentingnya menanamkan rasa hormat kepada guru sebagai wujud penghormatan juga kepada ilmu itu sendiri. Hal inilah yang sangat penting kita upayakan dalam pembelajaran afeksi dikarenakan apabila di dalam kelas maupun di luar kelas peserta didik minimal mampu menghormati gurunya maka akan berkelanjutan secara langsung dalam pergaulan dan juga kehidupan sosialnya.

Al-Zarnuji berpendapat bahwa seorang murid harus Ta'dzim (hormat) terhadap gurunya karena hal itu dapat menyebabkan adanya Barakah (manfaat dan kebaikan). Seorang murid tidak akan mendapatkan ilmu serta manfaat dari apa yang telah dikajinya kecuali jika selalu dibarengi dengan rasa hormat terhadap ilmu yang sedang dikaji, juga guru yang telah mengajarnya. Bahkan dibumbui anjuran yang bersifat mitos bagi seorang yang menginginkan keturunannya menjadi seorang 'âlim, untuk menghormati ulama dengan berbagai jalan diantaranya dengan memberikan sesuatu hal yang bermanfaat bagi para ulama. 4

Menurut al-zarnuji didalam melaksanakan pembelajaran maka harus selalu mengingat :

1. Niat

2. Cara memilih guru/sekolah dan teman

${ }^{4}$ Aliy As'ad, Terjemah Ta'lim Muta'allim (Kudus: Menara Kudus, tt), 19. 
3. Menghormati guru

4. Kesungguhan dan kontinuitas serta adanya cita-cita yang tinggi

5. Selalu berpasrah diri kepada tuhan

6. Saling mengasihi dan menasehati terhadap sesama

\section{Model Pengembangan Kognitif}

Model pengembangan kognitif dikembangkan oleh Lawrence Kohlberg. Model ini banyak diilhami oleh pemikiran John Dewey dan Jean Piaget yang berpendapat bahwa perkembangan manusia terjadi sebagai proses dari restrukturisasi kognitif yang berlangsung secara berangsur-angsur menurut urutan tertentu. Menurut Kohlberg, moral manusia itu berkembang melalui tiga tingkat dan setiap tingkat terdiridari dua tahap, yaitu $:^{5}$

\section{a. Tingkat Prakonvensional}

Pada tingkat ini setiap indifidu memandang moral berdasarkan kepentingannya sendiri. Artinya, pertimbangan moral didasarkan pada pandanganya secara individual tanpa menghiraukan rumusan atau aturan yang dibuat oleh masyarakat. Pada tingkatan prakonvensional ini terdiri atas dua tahap :

1. Orientasi Hukuman dan Kepatuhan

Pada tahap ini perilaku anak didasarkan kepada konsekuensi fisik yang akan terjadi.artinya, anak hanya berfikir bahwa perilaku yang benar itu adalah perilaku yang tidak akan mengakibatkan hukuman. Dengan demikian, setiap peraturan harus dipatuhi agar tidak menimbulkan konsekuensi negatitif.

2. Orientasi Instrumental-Relatif

Pada tahap ini perilaku anak didasarkan kepada rasa "adil" berdasarkan aturan permainan yang telah disepakati. Dikatakan adil manakala orang membalas perilaku kita yang dianggap baik. Dengan demikian perilaku perilaku itu didasarkan kepda saling menolong dan saling memberi. 


\section{b. Tingkat Konvensional}

Pada tahap ini anak mendekati masalah didasarkan pada hubungan individu masyarakat. Dengan demikian, pemecahan masalah bukan hanya didasarkan kepada rasa keadilan belaka, akan tetapi apakah pemecahan masalah itu sesuai dengan norma masyarakat atau tidak. Pada tingkat konvensional itu mempunyai 2 tahap, yaitu :

1. Keselarasan Interpersonal

Pada tahap ini ditandai dengan setiap perilaku yang ditampilkan individu didorong oleh keinginan untuk memenuhi harapan orang lain.

2. Sistem Sosial dan Kata Hati

Pada tahap ini perilaku individu bukan didasarkan pada dorongan untuk memenuhi harapan orang lain yang dihormatinya, akan tetapi didasarkan pada tuntutan dan harapan masyarakat.

c. Tingkat Portkonvesional

Pada tingkat ini perilaku bukan hanya didasarkan pada kepatuhan terhadap norma-norma masyarakat yang berlaku, akan tetapi didasari oleh adanya kesadaran sesuai dengan nilai-nilai yang dimilikinya secara individu. Tingkat ini juga terdiri dari 2 tahap, yaitu :

1. Kontrak Sosial

Pada tahap ini perilaku individu didasarkan pada kebenarankebenaran yang diakui oleh masyarakat.

2. Prinsip Etis yang Universal

Pada tahap terakhir, perilaku manusia didasarkan pada prinsipprinsip universal. Segala macam tindakan bukan hanya didasarkan sebagai kontrak social yang harus dipatuhi, akan tetapi didasarkan pada suatu kewajiban sebagai manusia. 


\section{Teknik Mengklarifikasi Nilai}

Teknik mengklarifikasi nilai (value clarification technique) atau sering disingkat VCT dapat diartikan sebagai teknik pengajaran untuk membantu siswa dalam mencari dan menentukan suatu nilai yang dianggap baik dalam menghadapi suatu persoalan melalui proses menganalisis nilai yang sudah ada dan tertanam dalam diri siswa. $^{6}$

Kelemahan yang sering terjadi dalam proses pembelajaran nilai atau sikap adalah proses pembelajaran dilakukan secara langsung oleh guru, artinya guru menanamkan nilai-nilai yang dianggapnya baik tanpa memperhatikan nilai yang sudah tertanam dalam diri siswa. Akibatnya, sering terjadi benturan atau konflik dalam diri siswa karena ketidakcocokan antara nilai lama yang sudah terbentuk dengan nilai baru yang ditanamkan oleh guru.

Menurut John Jarolimek, langkah pembelajaran dengan VCT dalam 7 tahap yang dibagi dalam 3 tingkat: $^{7}$

\section{Kebebasan Memilih}

Pada tingkat ini ada 3 tahap:

a. Memilih secara bebas

b. Memilih dari beberapa alternative

c. Memilih setelah dilakukan analisis pertimbangan konsekuensi yang akan timbul.

\section{Menghargai}

Ada 2 tahap:

a. Adanya perasaan senang dan bangga dengan nilai yang menjadi pilihannya.

b. Menegaskan nilai yang sudah menjadi bagian integral dalam dirinya di depan umum.

\section{Berbuat}

Terdiri atas 2 yaitu:

a. Kemeuan dan kemampuan untuk mencoba dan melaksanakannya

b. Mengulangi perilaku sesuai dengan nilai pilihannya. 


\section{Kesulitan Dalam Pembelajaran Afektif}

Ada beberapa kesulitan yang diantaranya $:^{8}$

Pertama, selama ini proses pendidikan sesuai dengan kurikulum yang berlaku cenderung diarahkan untuk pembentukan intelektual. Dengan demikian, keberhasilan proses pendidikan dan proses pembelajaran disekolah ditentukan oleh criteria kemampuan intelektual (kemampuan kognitif). Hal ini dapat dilihat dari berbagai macam bentuk evaluasi yang dilakukan baik evaluasi tingkat sekolah, tingkat wilayah, maupun evaluasi nasional yang diarahkan kepada kemampuan anak menguasai materi pelajaran.

Kedua, sulitnya melakukan control karena banyaknya factor yang dapat mempengaruhi perkembangan sikap seseorang. Pengembangan kemampuan sikap baik melalui proses pembiasaan maupun modeling bukan hanya ditentukan oleh factor guru, akan tetapi juga factor-faktor lain terutama factor lingkungan.

Ketiga, keberhasilan pembentukan sikap tidak bisa dievaluasi dengan segera. Berbeda dengan pembentukan aspek kognitif dan aspek keterampilan yang hasilnya dapat diketahui setelah proses pembelajaran berakhir, maka keberhasilan dari pembentukan sikap baru dapat dilihat pada rentang waktu yang cukup panjang.

Keempat, pengaruh kemajuan teknologi, khususnya teknilogi informasi yang menyuguhkan aneka pilihan program acara, berdampak pada pembentukan karakter anak. Tidak bisa kita pungkiri, program-program televisi, misalnya yang banyak menayangkan program acara produksi luar yang memiliki latar budaya yang berbeda, dan banyak ditonton oleh anak-anak, sangat berpengaruh dalam pembentukan sikap dan mental anak. 


\section{DAFTAR PUSTAKA}

Wina Sanjaya, Strategi Pembelajaran Beriorentasi Standar Proses Pendidikan.(Jakarta: Kencana, 2010),276.

kosasih Djahiri, Teknik Klarifikasi Nilai (Jakarta: P3G, 1980), 48.

Jarolimek, John, Social Studies Competiencies and skills: learning to teach as an Intern, (New York: Mac Millan Publishing Co.In, 1977), 87

As'ad, Aliy, Terjemah Ta'lim Muta'allim, Judus: Menara Kudus, tt.

Djahiri. A. Kosasih, Teknik Klarifikasi Nilai, Jakarta: P3G, 1980.

Gulo. W, Strategi Belajar Mengajar. Jakarta: Grasindo, 2002.

Jarolimek, John, Social Studies Competiencies and skills: learning to teach as an Intern, New York: Mac Millan Publishing Co.In, 1977.

Sanjaya. Wina, Strategi Pembelajaran Beriorentasi Standar Proses Pendidikan. Jakarta: Kencana, 2010.

UU No.20 Tahun 2003 Tentang Sistem Pendidikan Nasional. 